\title{
Antibacterial activity of jackfruit leaves extracts and the interference on antimicrobial susceptibility of enteropathogen
}

\author{
Dhierllate Ferreira de SOUSA ${ }^{1}$, Pedro Costa CAMPOS FILHO ${ }^{1}$, Aline Oliveira da CONCEIÇÃO ${ }^{1}$
}

\begin{abstract}
The objective of the present study was to evaluate the antimicrobial potential of Artocarpus heterophyllus dry leaves extracts on S. enterica and E. coli and their interaction with conventional antimicrobials. Dried powdered leaves were used to produce hexane (Hex), methanolic $(\mathrm{MeOH})$ and ethanolic residue (EtOHr) extracts. The antimicrobial test was performed against Escherichia coli, ATCC 25922, E. coli EPEC, CDC 086H35, and Salmonella enterica serotype Enteritidis phagotype 4 (SE PT4) through minimal inhibition concentration (MIC) and minimal bactericidal concentration (MBC). The agar diffusion technique, well and disc-variants were used to measure the antimicrobial effect of the plant extract combination with antimicrobial of clinical usage. We highlight the bactericidal effect of jackfruit tree leaves on E. coli and S. enterica SE PT4 at $7.2 \mathrm{mg} / \mathrm{mL}$ and the effect of the extracts on antimicrobial activity. The interaction between chloramphenicol and dry leaves extracts was characterized by both synergism and antagonism depending on extract type and bacteria used. The interaction between antimicrobial of clinical usage and jackfruit tree leaves extracts demonstrated changes in susceptibility profile of antimicrobials tending to an antagonist effect. As the jackfruit tree leaves may interfere on antimicrobials action, special attention should be given to its usage as traditional medicine in the treatment of food borne diseases.
\end{abstract}

Keywords: drug antagonism; drug synergism; medicinal plants; Escherichia coli; Salmonella; Artocarpus heterophyllus.

Practical Application: Antimicrobial activity and interaction of plant metabolites with antimicrobials.

\section{Introduction}

Foodborne diseases cause morbidity and mortality worldwide being a growing public health problem. According to the World Health Organization (WHO), the global burden of foodborne diseases is considerable, affecting individuals of all ages (World Health Organization, 2015). This report reveals that among hazards that contribute significantly to the burden of foodborne diseases there are 18 enteric pathogens. Among bacteria associated diseases, Salmonella spp. and Escherichia coli are the most frequent agents (Casburn-Jones \& Farthing, 2004). For example, in 2015, 59,000 cases of registered death were caused by Salmonella enterica; 37,000 by enteropathogenic E. coli (EPEC); and 26,000 by enterotoxigenic E. coli (ETEC) (World Health Organization, 2015).

The food related pathogens have become an ever-increasing threat to humans. The treatment of these agents is centered in the management of electrolyte disturbances, although, in some cases, antimicrobial therapy is required (Centers for Disease Control and Prevention, 2004). In addition, the emergency of resistant microorganisms due to the indiscriminate use of antibiotics in animal food (Angulo et al., 2004; Mathew et al., 2007) and the pharmacological interaction between substances present in natural products (van Vuuren \& Viljoen, 2011) may be a constraint to the resolution of foodborne diseases.
Artocarpus heterophyllus Lam, Moraceae, is popularly known as jaqueira (Portuguese), jackfruit tree (English); jacquier (French); kapiak (Papua New Guinea); uto ni India (Fiji); 'uluinitia (Samoa) (Elevitch \& Manner, 2006). It is native of Western India, Malaysia, East Africa, Southeast Asia, Caribbean, Florida, Australia, Puerto Rico, and Pacific islands (Siqueira, 2006). The fruits are big, sweet flavored, and have a strong and characteristic scent (Prakash et al., 2009). They are widely used as food and as traditional medicine (Jagtap \& Bapat, 2010), ingested in natura or as sweets and homemade jelly (Fonseca, 2016). The seeds are used as ingredients of "multimixtures" in order to prepare cookies, desserts, and bread, as an alternative source of carbohydrate, protein, and iron (Landim et al., 2012).

All parts of jackfruit tree are used as traditional medicine. They are recommended for the treatment of inflammation, malarial fever, kidney stones (Araújo \& Lima, 2010), ulcers, infected wounds, diarrhea, fever, asthma, anemia, and dermatitis (Jagtap \& Bapat, 2010), as well as soothing (Madaleno, 2011). The seeds are used to heal sexual disorders due to its aphrodisiac properties (Fonseca, 2016).

Scientific evidence of the healing properties of different parts of the jackfruit tree has already been presented. Particular emphasis has been given in the literature to the antioxidant activity from 
leaf, bark, and fruit extracts (Loizzo et al., 2010; Omar et al., 2011), jacalin and artocarpin antiviral activity (Tamma et al., 2006), anticancer activity of artocarpin (Sun et al., 2017), anti-inflammatory activity of flavonoids isolated from the bark (Wei et al., 2005), and antibacterial (Khan et al., 2003a; Loizzo et al., 2010) and antifungal potential (Trindade et al., 2006) of several extracts and fractions. However, there is a lack of information on the antimicrobial potential of dry leaf extracts on S. enterica and E. coli and about the interaction of extracts and fractions with conventional antimicrobials, which is the object of this study.

\section{Material and Methods}

\subsection{Botanical field collection}

Leaves of jackfruit tree (A. heterophyllus) were collected from an Atlantic Forest fragment characterized by riparian secondary vegetation, in a dense ombrophylous and semideciduous seasonal forest on the roadside of the BR 415 Jorge Amado highway, in Ilhéus, Bahia, Brazil (14\%47'33" S and $39^{\circ} 11^{\prime} 0^{\prime \prime}$ W). The Botanical material was harvest twice, in November $20^{\text {th }}, 2017$ and March $19^{\text {th }}, 2018$, at the same location, in the morning. The weather average records on the day of collection were $00 \mathrm{~mm}$ of rainfall, $20.6^{\circ} \mathrm{C}$ to $20.1{ }^{\circ} \mathrm{C}$ of temperature, $96-97 \%$ humidity, and $-2.14 \mathrm{KJ}$. $\mathrm{m}^{2}$ radiation (OMM: 86699 ). Plant material was identified and confirmed by the botanist Prof. Luiz Alberto Matos and registered with the voucher number HUESC23705 at the State University of Santa Cruz herbarium.

\subsection{Plant extraction}

Leaves were dried under forced air ventilation at $50^{\circ} \mathrm{C}$ in a drying oven (Quimis Q317M-12, Diadema, Brazil) until constant weigh. Thus, $500 \mathrm{~g}$ of dried and powered material was submitted to ethanolic extraction for $72 \mathrm{~h}$, protected from light $(1.0 \mathrm{~L} ; \mathrm{w} / \mathrm{v})$, being sonicated for $1 \mathrm{~h}$ with the Ultra-Sonic equipment (Unique Ultrasonic Cleaner: USC - 3380a) every $24 \mathrm{~h}$ This procedure was repeated three times with the same dried material resulting in a final volume of $3 \mathrm{~L}$, which was filtered and the ethanol was evaporated under reduced pressure at $50{ }^{\circ} \mathrm{C}$ (SOLAB: SL-126).

\subsection{Ethanolic extract partition}

The liquid-liquid partition of ethanolic extract $(100 \mathrm{~g})$, called here the $\mathrm{cEtOH}$, was done using the technique proposed by Goulart et al. (2008) and described in Sousa et al. (2019). Briefly, the $\mathrm{cEtOH}(10 \mathrm{~g})$ was resuspended in $200 \mathrm{~mL}$ of EtOH/ $\mathrm{H}_{2} \mathrm{O}$ (1:2), homogenized and, after $12 \mathrm{~h}$, the insoluble residue was filtered. The hydroalcoholic solution was fractionated with hexane (QHEMIS, Jundiaí, Brazil), chloroform (QHEMIS, Jundiaí, Brazil), ethyl acetate (QHEMIS, Jundiaí, Brazil) and methanol (QHEMIS, Jundiaí, Brazil). This experimental step was performed three times. After assembling each solvent residue together and evaporated, fractions yielded $3.05 \mathrm{~g}$ (fHex), $3.87 \mathrm{~g}$ ( $\mathrm{fCHCl} 3$ ), $3.53 \mathrm{~g}$ (fEtAc), and $2.02 \mathrm{~g}(\mathrm{fMeOH})$. For each extract solvent was evaporated under reduced pressure at $50{ }^{\circ} \mathrm{C}$ (SOLAB: SL-126).

A stock solution of $10 \mathrm{mg} \cdot \mathrm{mL}^{-1}$ of each plant extract using $0.15 \%$ dimethylsufoxide (DMSO, SYNTH,Jundiaí, Brazil) in water solution as solvent was filtered using a $0.22 \mu \mathrm{m}$ pore membrane (Kasvi, São José do Pinhais, Brazil) and stored at $-8^{\circ} \mathrm{C}$ in aliquots of $1 \mathrm{~mL}$.

\subsection{Microorganisms}

The microorganisms used in this study were Escherichia coli ATCC 25922, E. coli EPEC, CDC 086H35, and Salmonella enterica serotype Enteritidis phagotype 4 (SE PT4), obtained from the Collection of Reference Microorganisms on Health Surveillance (CMRVS, FIOCRUZ-INCQ, Rio de Janeiro-RJ, Brazil).

All strains were cultivated and maintained in nutrient agar (NA) (Acumedia, João Narezzi Indaiatuba, Brazil) containing tubes from which the bacterial inoculum was solubilized in a $\mathrm{NaCl} 0.9 \%$ solution and standardized to $0.5 \mathrm{McF}$ arland $\left(1.5 \times 10^{8} \mathrm{UFC} / \mathrm{mL}\right)$ scale.

\subsection{Antibacterial essay}

The minimal inhibition concentration (MIC) and minimal bactericidal concentration (MBC) were obtained through the broth microdilution technique described by CLSI-M100-S22 (Clinical and Laboratory Standards Institute, 2012). For MIC determination, 96 well plates were filled with serial dilutions $(9.0 ; 8.1 ; 7.2 ; 6.3 ; 5.4 ; 4.5 ; 2.2 ; 1.2 \mathrm{mg} / \mathrm{mL})$ of the extract diluted in the brain heart infusion (BHI) broth (Kasvi, São José do Pinhais, Brazil) and $10 \mu \mathrm{L}$ of the bacterial inoculum, resulting in a final volume of $100 \mu \mathrm{L}$ per well. Plates were incubated at $37{ }^{\circ} \mathrm{C}$ for $24 \mathrm{~h}$. Chloramphenicol (NeoQuímica Anápolis, Brazil) at $50 \mu \mathrm{g} / \mathrm{mL}, \mathrm{BHI}$, and extracts without bacteria were used as controls. After the incubation period, $20 \mu \mathrm{L}$ of resazurin (Sigma-Aldrich, Darmstadt, Alemanha) (0.01\%) were added to each well to determine the bacterial growth (pink color) or inhibition (blue color). For MBC determination, $10 \mu \mathrm{L}$ of each well was transferred to a plate containing $20 \mathrm{~mL}$ NA and incubated for $24 \mathrm{~h}$ at $37^{\circ} \mathrm{C}$. Experiments were done in triplicates and repeated three times. The MBC was determined by lack of visible bacterial growth in NA after $24 \mathrm{~h}$.

\subsection{Effect of antimicrobial and plant extract combination evaluation}

The antimicrobial and plant extract interaction was evaluated through both the well-variant and disc-variant the agar diffusion technique using the methods. Protein, cell wall synthesis, and DNA synthesis inhibitors were used: ampicillin, ampicillin + sulbactam, cefepime, amoxicillin + clavulanate, cephalexin, penicillin $\mathrm{G}$, chloramphenicol, gentamicin, ciprofloxacin, and amikacin (CECON, São Paulo, Brazil).

For agar diffusion tests, the technique described in CLSIM100-S15 (Clinical and Laboratory Standards Institute, 2005) with adaptations was used. Briefly, a final concentration of $8.2 \mathrm{mg} / \mathrm{mL}$ of the extracts was poured on the agar at $45^{\circ} \mathrm{C}$. After solidification, microrganisms were inoculated by spreading over the entire agar surface. Then, antimicrobial paper discs (about $6 \mathrm{~mm}$ in diameter) were added at determined distance so as not to have interference between the halos. The diameters $(\mathrm{mm})$ of inhibitory zones were recorded after incubation 
time $(24 \mathrm{~h})$ at $37^{\circ} \mathrm{C}$. Results were expressed as a mean of two independent experiments.

Synergism, antagonism, or indifferent interaction was determined as described by Canton \& Onofre (2009). Synergy was considered when the difference between the initial antimicrobial diameter zone and the inhibition zone formed when the extracts were combined with antimicrobials was $\geq 2 \mathrm{~mm}$. When the combined zone was less than the diameter formed by the antimicrobial alone, the result was interpreted as antagonism; and when the zone diameter did not change, the result was expressed as indifferent. Tests were repeated twice.

\section{Results}

The potential antimicrobial activity and antimicrobial interaction of some jackfruit dry leaf extracts are presented in this study. First, the antimicrobial activity showed a bactericidal effect of $\mathrm{MeOH}, \mathrm{Hex}$ and EtOH extracts against E. coli and S. enterica SE PT4 at $\geq 7.2 \mathrm{mg} / \mathrm{mL}$. Between the three extracts used, the $\mathrm{MeOH}$ results are highlighted since it was active with less concentration against all bacterial strains used (Table 1).

Next, when the interaction between antimicrobials of clinical use and jackfruit tree leaf extracts was investigated (Table 2) there was not a specific relationship between the extract interaction and the mechanism of action of the antimicrobial. However, the changes in the susceptibility profile of some specific strains were remarkable, tending to an antagonist effect.

Interestingly, the $\mathrm{MeOH}$ extract showed synergic effect with $\beta$-lactamic ring (Ampicillin) and ribosomes 50S (chloramphenicol) acting antimicrobials against $S$. enterica SE PT4 and antagonism to the great majority of antimicrobial tested, with exception to cefepime, ciprofloxacin and gentamicin that showed an indifferent effect against $E$. coli EPEC. For this extract, only gentamycin had a severe antagonism resulting in conversion from susceptible to intermediate state for E. coli ATCC 25922 (Table 2).

Regarding the Hex extract, results showed that for the majority of antimicrobials an antagonist effect was visualized,

Table 1. Jackfruit leaves extracts Minimal Inhibitory Concentration (MIC) and Minimal Bactericidal Concentration (MBC).

\begin{tabular}{|c|c|c|c|c|c|c|c|c|}
\hline \multirow{3}{*}{ Microorganisms } & \multicolumn{8}{|c|}{ Extracts $(\mathrm{mg} / \mathrm{mL})$} \\
\hline & \multicolumn{2}{|c|}{$\mathrm{MeOH}$} & \multicolumn{2}{|c|}{ Hex } & \multicolumn{2}{|c|}{$\mathrm{EtOH}$} & \multicolumn{2}{|c|}{ CHLO } \\
\hline & MIC & $\mathrm{MBC}$ & MIC & $\mathrm{MBC}$ & MIC & $\mathrm{MBC}$ & MIC & $\mathrm{MBC}$ \\
\hline ATCC 25922 E. coli & $\geq 7.2$ & ${ }^{*}$ & $\geq 8.1$ & * & $\geq 8.1$ & $*$ & $\geq 50$ & * \\
\hline CDC $086 \mathrm{H} 35$ E. coli EPEC & $\geq 8.1$ & * & $\geq 9$ & * & $\geq 8.1$ & * & $\geq 50$ & * \\
\hline S. enterica SE PT4 & $\geq 7.2$ & * & $\geq 9$ & * & $\geq 9$ & * & $\geq 50$ & * \\
\hline
\end{tabular}

$\mathrm{MeOH}$ : methanolic extract; Hex: hexanic extract; EtOHr: ethanolic extract; CHLO: Chloramphenicol $50 \mu \mathrm{g} / \mathrm{mL} .{ }^{\star}$ Bactericidal action.

Table 2. Effect of jackfruit leaf extracts and their interaction with antimicrobials by the agar diffusion technique.

\begin{tabular}{|c|c|c|c|c|c|c|c|c|c|c|c|c|c|c|c|c|c|c|c|c|c|c|}
\hline \multirow{2}{*}{ Agents } & \multirow{2}{*}{ Ref. } & \multicolumn{7}{|c|}{ E. coli ATCC 25922} & \multicolumn{7}{|c|}{ E. coli EPEC CDC $086 \mathrm{H} 35$} & \multicolumn{7}{|c|}{ S. enteritidis SE PT4 } \\
\hline & & $\mathrm{AE}$ & $\mathrm{MeOH}$ & S/A & Hex & S/A & $\mathrm{EtOH}$ & $\mathrm{S} / \mathrm{A}$ & $\mathrm{AE}$ & $\mathrm{MeOH}$ & S/A & Hex & S/A & $\mathrm{EtOH}$ & S/A & $\mathrm{AE}$ & $\mathrm{MeOH}$ & $\mathrm{S} / \mathrm{A}$ & Hex & S/A & $\mathrm{EtOH}$ & S/A \\
\hline AMP 10 ug & $\geq 17$ & $\begin{array}{c}19.0 \\
(\mathrm{~S})\end{array}$ & $\begin{array}{c}18.5 \\
(\mathrm{~S})\end{array}$ & $\downarrow$ & $\begin{array}{c}23.7 \\
(\mathrm{~S})\end{array}$ & $\uparrow$ & $\begin{array}{c}21.0 \\
(\mathrm{~S})\end{array}$ & $\uparrow$ & $\begin{array}{c}11.0 \\
(\mathrm{R})\end{array}$ & $\begin{array}{c}10.5 \\
(\mathrm{R})\end{array}$ & $\downarrow$ & $\begin{array}{l}10.0 \\
\text { (R) }\end{array}$ & $\downarrow$ & $\begin{array}{c}10.3 \\
(\mathrm{R})\end{array}$ & $\downarrow$ & $\begin{array}{c}25.3 \\
(\mathrm{~S})\end{array}$ & $\begin{array}{c}27.5 \\
(\mathrm{~S})\end{array}$ & $\uparrow$ & $\begin{array}{c}27.0 \\
(S)\end{array}$ & $\downarrow$ & $\begin{array}{c}29.0 \\
(S)\end{array}$ & $\uparrow$ \\
\hline CPM 30 ug & $\geq 18$ & $\begin{array}{c}36.0 \\
(S)\end{array}$ & $\begin{array}{c}36.5 \\
(\mathrm{~S})\end{array}$ & $\downarrow$ & $\begin{array}{c}27.0 \\
(S)\end{array}$ & $\downarrow$ & $\begin{array}{c}29.0 \\
(\mathrm{~S})\end{array}$ & $\downarrow$ & $\begin{array}{c}40.0 \\
(S)\end{array}$ & $\begin{array}{c}40.0 \\
(\mathrm{~S})\end{array}$ & $\leftrightarrow$ & $\begin{array}{c}32.0 \\
(\mathrm{~S})\end{array}$ & $\downarrow$ & $\begin{array}{c}33.3 \\
(S)\end{array}$ & $\downarrow$ & $\begin{array}{c}40.0 \\
(\mathrm{~S})\end{array}$ & $\begin{array}{c}37.5 \\
(\mathrm{~S})\end{array}$ & $\downarrow$ & $\begin{array}{r}36.7 \\
(\mathrm{~S})\end{array}$ & $\downarrow$ & $\begin{array}{c}33.3 \\
(\mathrm{~S})\end{array}$ & $\downarrow$ \\
\hline ASB $20 \mathrm{ug}$ & $\geq 15$ & $\begin{array}{r}26.3 \\
(S)\end{array}$ & $\begin{array}{c}26.5 \\
(\mathrm{~S})\end{array}$ & $\downarrow$ & $\begin{array}{c}23.0 \\
(\mathrm{~S})\end{array}$ & $\downarrow$ & $\begin{array}{c}24.3 \\
(\mathrm{~S})\end{array}$ & $\downarrow$ & $\begin{array}{c}14.0 \\
\text { (I) }\end{array}$ & $\begin{array}{c}13.0 \\
\text { (I) }\end{array}$ & $\downarrow$ & $\begin{array}{l}14 \\
\text { (I) }\end{array}$ & $\leftrightarrow$ & $\begin{array}{c}13.3 \\
(\mathrm{R})\end{array}$ & $\downarrow$ & $\begin{array}{c}31.3 \\
(\mathrm{~S})\end{array}$ & $\begin{array}{c}32.5 \\
(\mathrm{~S})\end{array}$ & $\downarrow$ & $\begin{array}{r}30.7 \\
(\mathrm{~S})\end{array}$ & $\downarrow$ & $\begin{array}{c}29.7 \\
(\mathrm{~S})\end{array}$ & $\downarrow$ \\
\hline CHLO $30 \mathrm{ug}$ & $\geq 18$ & $\begin{array}{c}28.7 \\
(\mathrm{~S})\end{array}$ & $\begin{array}{c}29.0 \\
(\mathrm{~S})\end{array}$ & $\downarrow$ & $\begin{array}{r}23.7 \\
(\mathrm{~S})\end{array}$ & $\downarrow$ & $\begin{array}{c}27.5 \\
(\mathrm{~S})\end{array}$ & $\downarrow$ & $\begin{array}{c}32.0 \\
(\mathrm{~S})\end{array}$ & $\begin{array}{c}31.5 \\
(\mathrm{~S})\end{array}$ & $\downarrow$ & $\begin{array}{r}26.7 \\
(S)\end{array}$ & $\downarrow$ & $\begin{array}{c}29.5 \\
(\mathrm{~S})\end{array}$ & $\downarrow$ & $\begin{array}{c}32.7 \\
(\mathrm{~S})\end{array}$ & $\begin{array}{c}34.5 \\
(\mathrm{~S})\end{array}$ & $\uparrow$ & $\begin{array}{c}28.0 \\
(\mathrm{~S})\end{array}$ & $\downarrow$ & $\begin{array}{c}29.0 \\
(\mathrm{~S})\end{array}$ & $\downarrow$ \\
\hline CYP 5 ug & $\geq 18$ & $\begin{array}{c}28.7 \\
(\mathrm{~S})\end{array}$ & $\begin{array}{c}29.0 \\
(\mathrm{~S})\end{array}$ & $\downarrow$ & $\begin{array}{c}23.0 \\
(\mathrm{~S})\end{array}$ & $\downarrow$ & $\begin{array}{c}24.3 \\
(\mathrm{~S})\end{array}$ & $\downarrow$ & $\begin{array}{c}35.0 \\
(\mathrm{~S})\end{array}$ & $\begin{array}{c}35.0 \\
(\mathrm{~S})\end{array}$ & $\leftrightarrow$ & $\begin{array}{c}25.3 \\
(\mathrm{~S})\end{array}$ & $\downarrow$ & $\begin{array}{c}29.3 \\
(\mathrm{~S})\end{array}$ & $\downarrow$ & $\begin{array}{r}37.3 \\
(\mathrm{~S})\end{array}$ & $\begin{array}{c}35.0 \\
(S)\end{array}$ & $\downarrow$ & $\begin{array}{c}35.3 \\
(\mathrm{~S})\end{array}$ & $\downarrow$ & $\begin{array}{c}36.7 \\
(\mathrm{~S})\end{array}$ & $\downarrow$ \\
\hline GEN 10 ug & $\geq 15$ & $\begin{array}{c}15.3 \\
(\mathrm{~S})\end{array}$ & $\begin{array}{c}13.5 \\
\text { (I) }\end{array}$ & $\downarrow$ & $\begin{array}{l}14.3 \\
\text { (R) }\end{array}$ & $\downarrow$ & $\begin{array}{c}14.3 \\
\text { (I) }\end{array}$ & $\downarrow$ & $\begin{array}{c}15.0 \\
(\mathrm{~S})\end{array}$ & $\begin{array}{c}15.0 \\
(\mathrm{~S})\end{array}$ & $\leftrightarrow$ & $\begin{array}{c}15.0 \\
(\mathrm{~S})\end{array}$ & $\leftrightarrow$ & $\begin{array}{c}17.5 \\
(\mathrm{~S})\end{array}$ & $\uparrow$ & $\begin{array}{c}15.7 \\
(\mathrm{~S})\end{array}$ & $\begin{array}{c}17.5 \\
(\mathrm{~S})\end{array}$ & $\downarrow$ & $\begin{array}{l}12.0 \\
\text { (R) }\end{array}$ & $\downarrow$ & $\begin{array}{r}12.3 \\
(\mathrm{R})\end{array}$ & $\downarrow$ \\
\hline AMC 30 ug & $\geq 18$ & $\begin{array}{r}28.7 \\
(\mathrm{~S})\end{array}$ & $\begin{array}{c}29.0 \\
(\mathrm{~S})\end{array}$ & $\downarrow$ & $\begin{array}{c}25.3 \\
(\mathrm{~S})\end{array}$ & $\downarrow$ & $\begin{array}{c}25.3 \\
(\mathrm{~S})\end{array}$ & $\downarrow$ & $\begin{array}{l}11.3 \\
\text { (R) }\end{array}$ & $\begin{array}{c}11.0 \\
(\mathrm{R})\end{array}$ & $\downarrow$ & $\begin{array}{l}14.0 \\
\text { (R) }\end{array}$ & $\uparrow$ & $\begin{array}{c}20.8 \\
(\mathrm{~S})\end{array}$ & $\uparrow$ & $\begin{array}{c}29.3 \\
(\mathrm{~S})\end{array}$ & $\begin{array}{c}22.5 \\
(\mathrm{~S})\end{array}$ & $\downarrow$ & $\begin{array}{c}33.0 \\
(\mathrm{~S})\end{array}$ & $\uparrow$ & $\begin{array}{c}30.3 \\
(\mathrm{~S})\end{array}$ & $\downarrow$ \\
\hline AMI 30 ug & $\geq 17$ & $\begin{array}{r}22.3 \\
(\mathrm{~S})\end{array}$ & $\begin{array}{c}22.5 \\
(\mathrm{~S})\end{array}$ & $\downarrow$ & $\begin{array}{c}18.0 \\
(\mathrm{~S})\end{array}$ & $\downarrow$ & $\begin{array}{c}20.3 \\
(\mathrm{~S})\end{array}$ & $\downarrow$ & $\begin{array}{c}22.3 \\
(\mathrm{~S})\end{array}$ & $\begin{array}{c}22.0 \\
(\mathrm{~S})\end{array}$ & $\downarrow$ & $\begin{array}{c}19.0 \\
(S)\end{array}$ & $\downarrow$ & $\begin{array}{c}15.8 \\
\text { (I) }\end{array}$ & $\downarrow$ & NT & NT & - & NT & - & NT & - \\
\hline CFM 30 ug & $\geq 19$ & $\begin{array}{r}23.7 \\
(\mathrm{~S})\end{array}$ & $\begin{array}{c}23.5 \\
(\mathrm{~S})\end{array}$ & $\downarrow$ & $\begin{array}{c}11.3 \\
(\mathrm{R})\end{array}$ & $\downarrow$ & $\begin{array}{c}17.5 \\
(\mathrm{I})\end{array}$ & $\downarrow$ & $\begin{array}{c}10.7 \\
(\mathrm{R})\end{array}$ & $\begin{array}{c}10.5 \\
(\mathrm{R})\end{array}$ & $\downarrow$ & $\begin{array}{l}11.3 \\
\text { (R) }\end{array}$ & $\downarrow$ & $\begin{array}{c}12.8 \\
(\mathrm{R})\end{array}$ & $\uparrow$ & NT & NT & - & NT & - & NT & - \\
\hline
\end{tabular}

PEN 10 ug

Ref. Minimal values in millimeters determined by M10021 (Clinical and Laboratory Standards Institute, 2011) to consider a bacteria sensible to the antimicrobial. AE: antimicrobial efficacy on bacteria tested; (S): Susceptible; (I): Intermediate; (R): Resistant; (-) no inhibition zone; S/A: synergism/antagonism effect ( $\uparrow$ ) Synergistic; ( $\downarrow$ ) Antagonistic; ( $\leftrightarrow)$ Indifferent; NT: Not tested; AMP: Ampicyllin; CPM: Cefepime; ASB: Ampicyllin+Sulbactam; CHLO: Chloramphenicol; CYP: Cyprofloxacin; GEN: Gentamycin; AMC: Amoxicyllin+Clavulanic acid; AMI: Amicacyn; CFM: Cefixime; PEN: Penicillin. The results are the mean of two independent experiments. 
being more pronounced for gentamicin and cefixime, which turned from the sensitive to the resistant state against $E$. coli ATCC 25922 and S. enterica SE PT4. This extract had a promising result only for ampicillin against E. coli ATCC 25922, and amoxicillin+clavulanate against E. coli EPEC and S. enterica SE PT4a (Table 2).

Finally, the EtOH extract interacted with antimicrobials as an antagonist. It is worth noting that the interaction of this extract with gentamycin and cefixime for E. coli ATCC 25922, ampicillin+sulbactam and amikacin for E. coli EPEC, and gentamycin for S. enterica SE PT4 resulted in antagonism, with conversion of the susceptibility profile. For this extract, the only beneficial interaction observed took place when amoxicillin+clavulanate was tested, which presented a synergistic effect (Table 1).

\section{Discussion}

The antimicrobial activity of jackfruit tree against foodborne pathogens has already been reported in the literature. Specifically from leaves, crude methanolic (Khan et al., 2003b) and aqueous (Loizzo et al., 2010) extracts has been shown to be effective against E. coli, (ATCC 35150), Salmonella typhimurium (ATCC 14028), and Salmonella enterica (ATCC 10708). Moreover, methanolic and ethanolic fractions showed to be active against antibiotic resistant bacteria such as methicillin resistant S. aureus (Karthy et al., 2009). In the present study we corroborate the bactericidal effect of jackfruit leaf extracts on foodborne pathogens (Cavalcante et al., 2013; Jagtap \& Bapat, 2010) adding results from two other strains, the E. coli ATCC 25922 and S. enterica SE PT4. In our study, the best extract regarding inhibitory concentration was the $\mathrm{MeOH}$ extract, which presented bactericidal effect at $\geq 7.2 \mathrm{mg} / \mathrm{mL}$ against the three bacterial strains used. In the literature, although with a smaller bacterial spectrum, the best result was found using the ethanolic extract compared to extract concentration (Barbosa, 2017). It is important to note that the solvent plays a role in the selection of natural compounds class with biological activity (Do et al., 2014) reinforcing the need to perform antibacterial screening of certain plants with different solvents before discarding their biological activity.

In addition, geographic, and phenological aspects about the collection time, part of the plant, and especially the processing of plant parts before solvent extraction played an important role in qualitative and quantitative composition of secondary metabolites (Yang et al., 2018) and might affect the biological activity of some plants. From the jackfruit tree leaves found specifically in the Atlantic forest fragment in the climate conditions described here, it was possible to obtain an anti- E. coli ATCC25922 and S. enterica SE PT4 extract with more polar molecules by ethanolic and methanolic extraction.

Concerning the interaction between conventional antimicrobials and extracts, to our knowledge, this is the first report of the interference of $A$. heterophyllus leaves extract with these substances. Results showed that the three extracts tended to have an antagonistic effect on antimicrobials. Changes in the susceptibility status were observed, highlighting the synergistic effect of the $\mathrm{EtOH}$ extract combined with amoxicillin+clavulanate for E. coli EPEC. The non-specific effect regarding bacteria and antimicrobials revealed that the interference of plant compounds may have more than one mechanism of action. This was specially noted for the Hex extract with gentamycin, which inhibits the $30 \mathrm{~S}$ ribosome, or cefixime, which acts via competitive inhibition of the transpeptidase enzyme.

\section{Conclusion}

In summary, in this work, we did not only demonstrate the antimicrobial potential of jackfruit tree leaf extracts but also the singular interaction of these extracts with clinically used antimicrobials. Regarding this interaction, we emphasize the importance that must be given to the administration of phytotherapics or homemade teas during the oral treatment of bacterial borne disease. However, in order to provide further conclusions on the consumption of plant derivatives in support of disease treatment, further studies about the interaction between plant products and antimicrobials should be conducted in in vivo models.

\section{References}

Angulo, F. J., Nargund, V. N., \& Chiller, T. C. (2004). Evidence of an association between use of anti-microbial agents in food animals and anti-microbial resistance among bacteria isolated from humans and the human health consequences of such resistance. Journal of Veterinary Medicine Series B: Infectious Diseases and Veterinary Public Health, 51(8-9), 374-379. http://dx.doi.org/10.1111/j.14390450.2004.00789.x. PMid:15525369.

Araújo, N. G., \& Lima, L. R. P. (2010). Utilização de Artocarpus heterophyllus no tratamento de cálculos de oxalato de cálcio. Infarma, 22(11-12), 3-7.

Barbosa, C. A. (2017). Caracterização microbiológica, genotípica de Escherichia coli provenientes de Mytella guyanensis e sensibilidade a antimicrobianos (Dissertação de mestrado). Universidade Federal do Recôncavo da Bahia, Cruz das Almas.

Canton, M., \& Onofre, S. B. (2009). Interferência de extratos da Baccharis dracunculifolia DC., Asteraceae, sobre a atividade de antibióticos usados na clínica. Revista Brasileira de Farmacognosia, 20(3), 348354. http://dx.doi.org/10.1590/S0102-695X2010000300010.

Casburn-Jones, A. C., \& Farthing, M. J. G. (2004). Management of infectious diarrhoea. Gut, 53(2), 296-305. http://dx.doi.org/10.1136/ gut.2003.022103. PMid:14724167.

Cavalcante, G. M., Lima, J. F. No., Bomfim, E. O., \& Flória-Santos, M. J. (2013). Atividade antimicrobiana de Artocarpus heterophyllus Lam. (Moraceae) sobre o desenvolvimento de Streptococcus pneumoniae e Escherichia coli. Scientia Plena, 9(2), 029902.

Centers for Disease Control and Prevention - CDC. Morbidity and Mortality Weekly Report. (2004). Diagnosis and management of foodborne illnesses: safer, healthier people. Atlanta: CDC.

Clinical and Laboratory Standards Institute - CLSI. (2005). Normas de Desempenho para Testes de Sensibilidade Antimicrobiana: $15^{\circ}$ Suplemento informative. (25th ed., Vol. 1, Approved Standard, M100-S15). Wayne, PA: CLSI.

Clinical and Laboratory Standards Institute - CLSI. (2011). Suggested grouping of US-FDA approved antimicrobial agents that should be considered for routine testing and reporting on nonfastidious organisms by clinical laboratories. Wayne, PA: CLSI. 
Clinical and Laboratory Standards Institute - CLSI. (2012). Performance standards for antimicrobial; susceptibility testing: informational supplement (No. 3, Approved Standard, M100-S22). Wayne, PA: CLSI.

Do, Q. D., Angkawijaya, A. E., Tran-Nguyen, P. L., Huynh, L. H., Soetaredjo, F. E., Ismadji, S., \& Ju, Y. H. (2014). Effect of extraction solvent on total phenol content, total flavonoid content, and antioxidant activity of Limnophila aromatica. Yao Wu Shi Pin Fen Xi, 22(3), 296-302. http://dx.doi.org/10.1016/j.jfda.2013.11.001. PMid:28911418.

Elevitch, C. R., \& Manner, H. I. (2006). Artocarpus heterophyllus (jackfruit). In C. R. Elevitch (Ed.), Species profiles for pacific island agroforestry: ecological, economic, and cultural renewal. permanent agriculture resources (pp. 1-17). Holualoa: Permanent Agriculture Resources. Retrieved from https://agroforestry.org/images/pdfs/A.heterophyllus-jackfruit.pdf

Fonseca, C. (2016). Desidratação da jaca (Artocarpus heterophyllus Lam. ) de São Tomé e Príncipe: Análise físico-química de amostras frescas e desidratadas (Dissertação de mestrado). Lisboa: Instituto Superior de Agronomia, Universidade de Lisboa. Retrieved from http://hdl.handle.net/10400.5/13378

Goulart, S. M., Queiroz, M. E. L. R., Neves, A. A., \& Queiroz, J. H. (2008). Low-temperature clean-up method for the determination of pyrethroids in milk using gas chromatography with electron capture detection. Talanta, 75 (5), 1320-1323. Retrieved from https://doi. org/10.1016/j.talanta.2008.01.058

Jagtap, U. B., \& Bapat, V. A. (2010). Artocarpus: a review of its traditional uses, phytochemistry and pharmacology. Journal of Ethnopharmacology, 129(2), 142-166. http://dx.doi.org/10.1016/j. jep.2010.03.031. PMid:20380874.

Karthy, E. S., Ranjitha, P., \& Mohankumar, A. (2009). Antimicrobial potential of plant seed extracts against multidrug resistant methicillin resistant Staphylococcus aureus (MDR-MRSA). International Journal of Biology, 1(1). http://dx.doi.org/10.5539/ijb.v1n1p34.

Khan, A., Safdar, M., Ali Khan, M. M., Khattak, K. N., \& Anderson, R. (2003a). Cinnamon improves glucose and lipids of people with type 2 diabetes. Diabetes Care, 26(12), 3215-3218. http://dx.doi. org/10.2337/diacare.26.12.3215. PMid:14633804.

Khan, M. R., Omoloso, A. D., \& Kihara, M. (2003b). Antibacterial activity of Artocarpus heterophyllus. Fitoterapia, 74(5), 501-505. http://dx.doi.org/10.1016/S0367-326X(03)00120-5. PMid:12837372.

Landim, L., Bonomo, R., Reis, R., Silva, S., Veloso, C., \& Fontan, R. (2012). Formulation of meatballs with jackfruit seed flour. UNOPAR Científica. Ciências Biológicas e da Saúde, 14(2), 87-93.

Loizzo, M. R., Tundis, R., Chandrika, U. G., Abeysekera, A. M., Menichini, F., \& Frega, N. G. (2010). Antioxidant and antibacterial activities on foodborne pathogens of Artocarpus heterophyllus lam. (Moraceae) leaves extracts. Journal of Food Science, 75(5), M291-M295. http:// dx.doi.org/10.1111/j.1750-3841.2010.01614.x. PMid:20629886.

Madaleno, I. M. (2011). Plantas da medicina popular de São Luís, Brasil. Boletim do Museu Paraense Emílio Goeldi. Ciências Humanas, 6(2), 273-286. http://dx.doi.org/10.1590/S1981-81222011000200002.

Mathew, A. G., Cissell, R., \& Liamthong, S. (2007). Antibiotic resistance in bacteria associated with food animals: a United States perspective of livestock production. Foodborne Pathogens and Disease, 4(2), 115-133. http://dx.doi.org/10.1089/fpd.2006.0066. PMid:17600481.
Omar, H. S., El-Beshbishy, H. A., Moussa, Z., Taha, K. F., \& Singab, A. N. B. (2011). Antioxidant activity of Artocarpus heterophyllus Lam. (Jack Fruit) leaf extracts: remarkable attenuations of hyperglycemia and hyperlipidemia in streptozotocin-diabetic rats. The Scientific World Journal, 11, 788-800. http://dx.doi.org/10.1100/tsw.2011.71. PMid:21479350.

Prakash, O., Kumar, R., Mishra, A., \& Gupta, R. (2009). Artocarpus heterophyllus (Jackfruit): An overview. Pharmacognosy Reviews, 3(6), 353-358.

Siqueira, J. (2006). Bioinvasão vegetal: dispersão e propagacão de espécies nativas e invasoras exóticas no campus da Pontifícia Universidade Católica do Rio de Janeiro (PUC-RIO). Revista Pesquisas, Botânica, (57), 319-330. Retrieved from http://www.anchietano.unisinos.br/ publicacoes/botanica/botanica57/artigo16.pdf

Sousa, D.F., Campos Filho, P.C., Fernandes, M. J. B., Oliveira, R.A. \& Conceicao A.O. (2019). In vitro non cytotoxic anti-herpesvirus properties of jackfruit tree (Artocarpus heterophyllus Lam.) leaves extracts. Journal of Medicinal Plant Research, 14(5), 225-231.

Sun, G., Zheng, Z., Lee, M. H., Xu, Y., Kang, S., Dong, Z., Wang, M., Gu, Z., Li, H., \& Chen, W. (2017). Chemoprevention of colorectal cancer by artocarpin, a dietary phytochemical from Artocarpus heterophyllus. Journal of Agricultural and Food Chemistry, 65(17), 3474-3480. http://dx.doi.org/10.1021/acs.jafc.7b00278. PMid:28391699.

Tamma, S. M. L., Chung, K. W., Patel, T., Balan, S. P., \& Pahwa, S. (2006). p38 MAPK plays a role in IL-4 synthesis in jacalin plus CD28-stimulated CD4+ T cells--II. Journal of Leukocyte Biology, 79(6), 1339-1347. http://dx.doi.org/10.1189/jlb.0905513. PMid:16554354.

Trindade, M. B., Lopes, J. L. S., Soares-Costa, A., MonteiroMoreira, A. C., Moreira, R. A., Oliva, M. L. V., \& Beltramini, L. M. (2006). Structural characterization of novel chitin-binding lectins from the genus Artocarpus and their antifungal activity. Biochimica et Biophysica Acta. Proteins and Proteomics, 1764(1), 146-152. http://dx.doi.org/10.1016/j.bbapap.2005.09.011. PMid:16257591.

van Vuuren, S., \& Viljoen, A. (2011). Plant-based antimicrobial studies methods and approaches to study the interaction between natural products. Planta Medica, 77(11), 1168-1182. http://dx.doi. org/10.1055/s-0030-1250736. PMid:21283954.

Wei, B. L., Weng, J. R., Chiu, P. H., Hung, C. F., Wang, J. P., \& Lin, C. N. (2005). Antiinflammatory flavonoids from Artocarpus heterophyllus and Artocarpus communis. Journal of Agricultural and Food Chemistry, 53(10), 3867-3871. http://dx.doi.org/10.1021/ jf047873n. PMid:15884809.

World Health Organization - WHO. (2015). Areas of work Databases Document centre WHO estimates of the global burden of foodborne diseases: foodborne diseases burden epidemiology reference group 2007-2015. Switzerland.

Yang, L., Wen, K.-S., Ruan, X., Zhao, Y.-X., Wei, F., \& Wang, Q. (2018). Response of plant secondary metabolites to environmental factors. Molecules, 23(4), 762. http://dx.doi.org/10.3390/molecules23040762. PMid:29584636. 